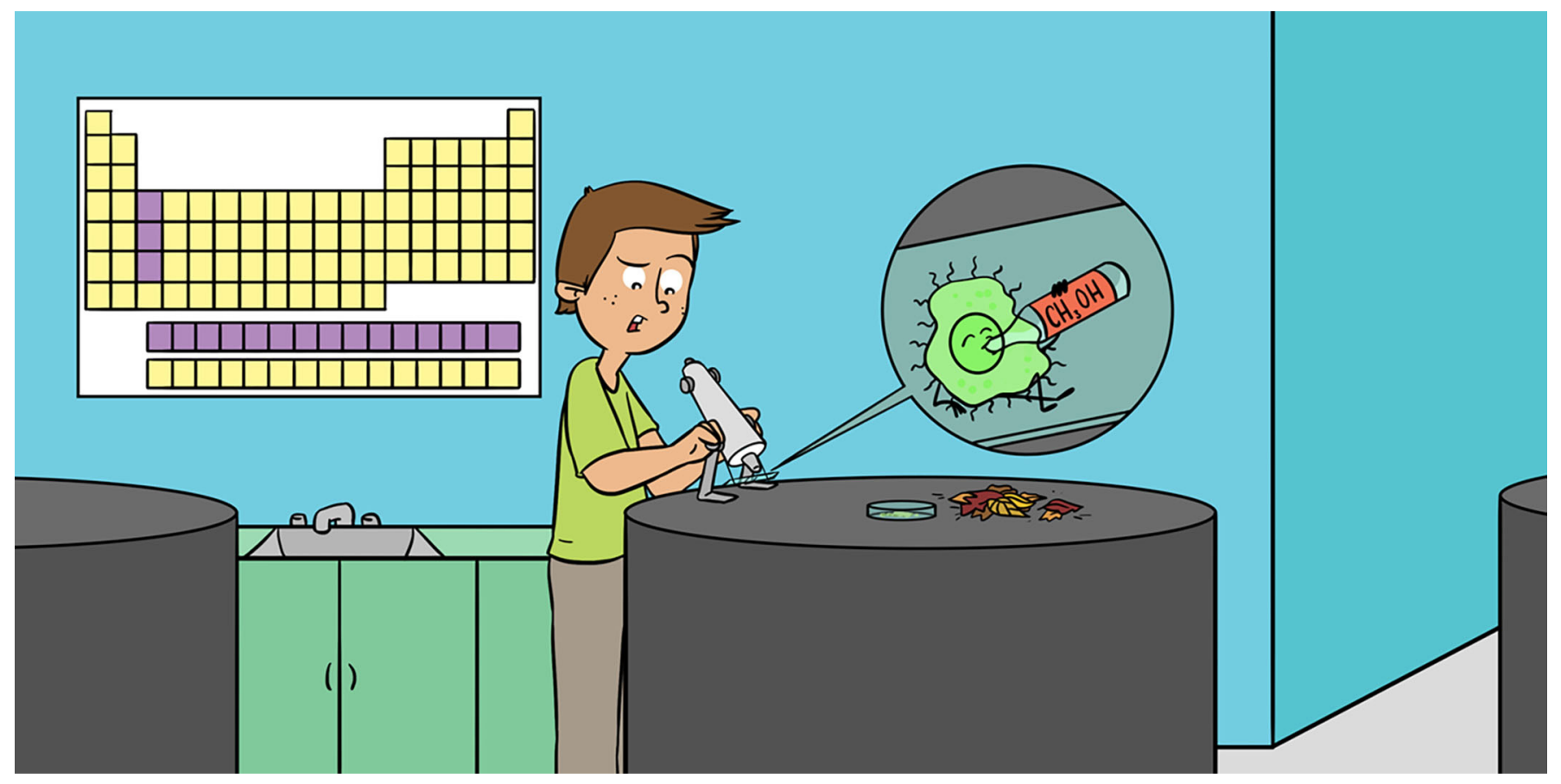

\title{
HOW RARE ARE RARE-EARTH ELEMENTS IN LIVING THINGS?
}

\author{
Rocío Bustillos-Cristales ${ }^{1}$, Yagul Pedraza-Pérez ${ }^{2}$ and Luis Ernesto Fuentes-Ramírez ${ }^{1 *}$ \\ ${ }^{1}$ Instituto de Ciencias, Benemérita Universidad Autónoma de Puebla, Puebla, Mexico \\ ${ }^{2}$ Área de Biología, Universidad Popular Autónoma del Estado de Puebla, Puebla, Mexico
}

YOUNG REVIEWER:

KONSTANTIN

AGE: 14
Rare-earth elements (REEs) are a group of metallic chemical elements that share some properties and that despite their name are not too rare in the Earth's crust. Until recently, we did not know of any REEs that were necessary for any living organism. Now we know that there are some bacteria that use REEs to perform reactions that let them consume alcohol. Humans are also interested in REEs because these elements are valuable for many technological applications. In this article, we will explain the only known participation of REEs in living organisms and explain why future research on REEs is important.

\section{HOW RARE ARE THE RARE-EARTH ELEMENTS?}

All substances, including the materials that make up living organisms, are composed of atoms. Atoms are very tiny particles, so small that they cannot be seen even with the most powerful microscopes. Atoms are made up from other, even tinier particles called neutrons, protons, 
CHEMICAL

ELEMENTS

Pure substances made up of atoms with the same number of protons.

\section{RARE-EARTH}

\section{ELEMENTS}

(REEs) metal elements including the lanthanides and the elements scandium and yttrium.

\section{LANTHANIDES}

Soft metallic elements grouped in the periodic table from the atomic numbers 57 (lanthanum) to 71 (lutetium)

\section{METHANOL}

The simplest alcohol. It is naturally synthesized by plants. and electrons. When atoms have the same number of protons, they are considered to be of the same class of material and are called chemical elements. Some chemical elements that you may have heard of include oxygen, carbon, and iron. Chemists have organized all the elements according to their characteristics in the periodic table of the elements (https://www.rsc.org/periodic-table).

Rare-earth elements (REEs) are those elements that include the group called lanthanides, plus the elements scandium and yttrium. They are soft metals that are all similar in color, and they get rusty when exposed to air. REEs are born in the enormous pressures and temperatures inside supernovas, and from there they are thrown out into the rest of the universe, including planet Earth. The REE promethium is also produced on our planet, in human-made nuclear reactors. Some of the 17 existing REEs are very rare on Earth, but most are relatively common (Figure 1). REEs are present in the Earth's crust, but also in its deeper layers of the earth and in rivers, lakes, and seas. REEs are highly valuable to humans, because they have many important uses. REEs are used to make certain medical devices and technologies, and they are also used to make some types of lamps, batteries, paints, high-performance magnets, lasers, and so on (Figure 1).

REEs are commonly obtained through mining mineral ores. As we continue to use REEs, we will reduce the earth's supply of them. Our best strategy for the future may be to recycle REEs so that we can use them again. Recycling will also be helpful because REEs could become dangerous contaminants of the environment.

\section{RARE EARTH ELEMENTS IN LIVING ORGANISMS}

A lot of chemical elements are necessary for the healthy life of any living organism. The elements that are present in the highest quantities in living organisms are oxygen, carbon, hydrogen, nitrogen, sulfur, and phosphorus. These elements make up about $99 \%$ of their living mass. Until recently, no REEs had been detected in any living organism, but now we know that REEs are important to certain bacteria that consume the alcohol called methanol (Figure 2) [1, 2]. This was a great discovery since many scientists previously thought that no living organisms needed REEs.

It turns out that many of the types of bacteria that consume methanol need REEs, but in very low quantities. For example, most methanol-consuming bacteria can use methanol to survive and reproduce in the presence of $\sim 0.004 \mathrm{~g}$ of the REE cerium per liter-a very tiny amount. So far, there is no experimental evidence that REEs are important for organisms like plants and animals. However, one research group found genes for proteins that probably associate with REEs in several different organisms, including humans [3]. This is quite 


\section{Figure 1}

The most abundant rare earth elements are lanthanum, cerium, praseodymium, and neodymium. REEs have many important uses in manufacturing, several of which are shown here.

\section{Lanthanides}

Abundance and some uses

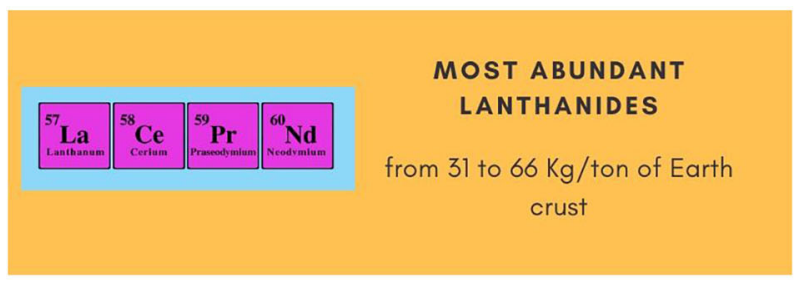

HIGH POWER MAGNETS
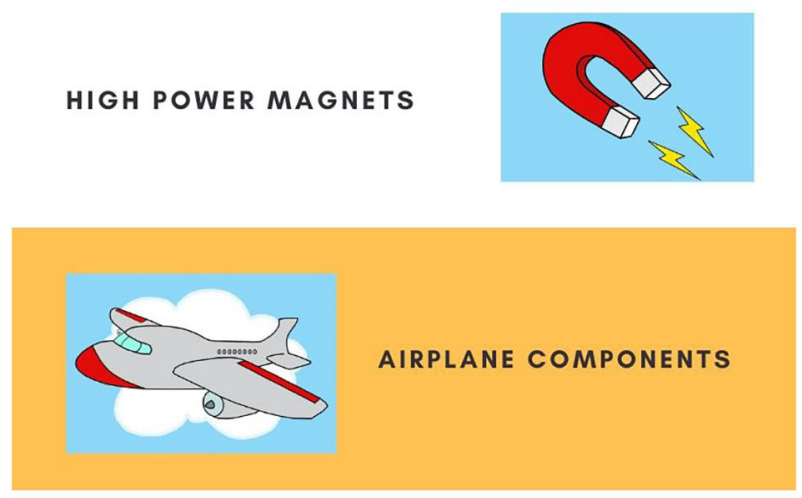

LASER DEVICES
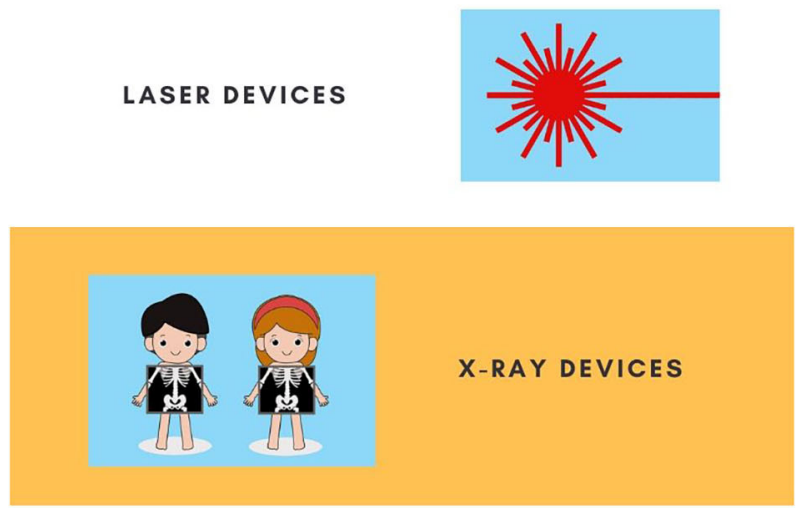

TELESCOPE LENSES

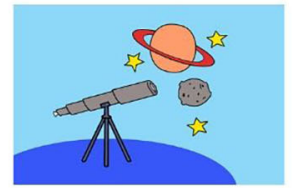

interesting, and future research will hopefully determine if REEs are also used by non-bacterial organisms. 
Figure 2

Methylotrophic

bacteria need rare earth elements or calcium to use methanol as food.

On the left, you can see that bacteria cannot use methanol as food until REEs or calcium $\left(\mathrm{Ca}^{++}\right)$are also present. In the presence of REEs or $\mathrm{Ca}^{++}$, the concentration of methanol goes down over time as the bacteria use it, while the number of bacterial cells goes up, because the methanol provides them with the energy to divide.

\section{METHYLOTROPHIC BACTERIA}

Bacterial microorganisms that can consume organic substances with once atom of carbon, for instance methanol or methane.

\section{METHANE}

The principal component of natural gas and one of the gases that contributes to the greenhouse effect.

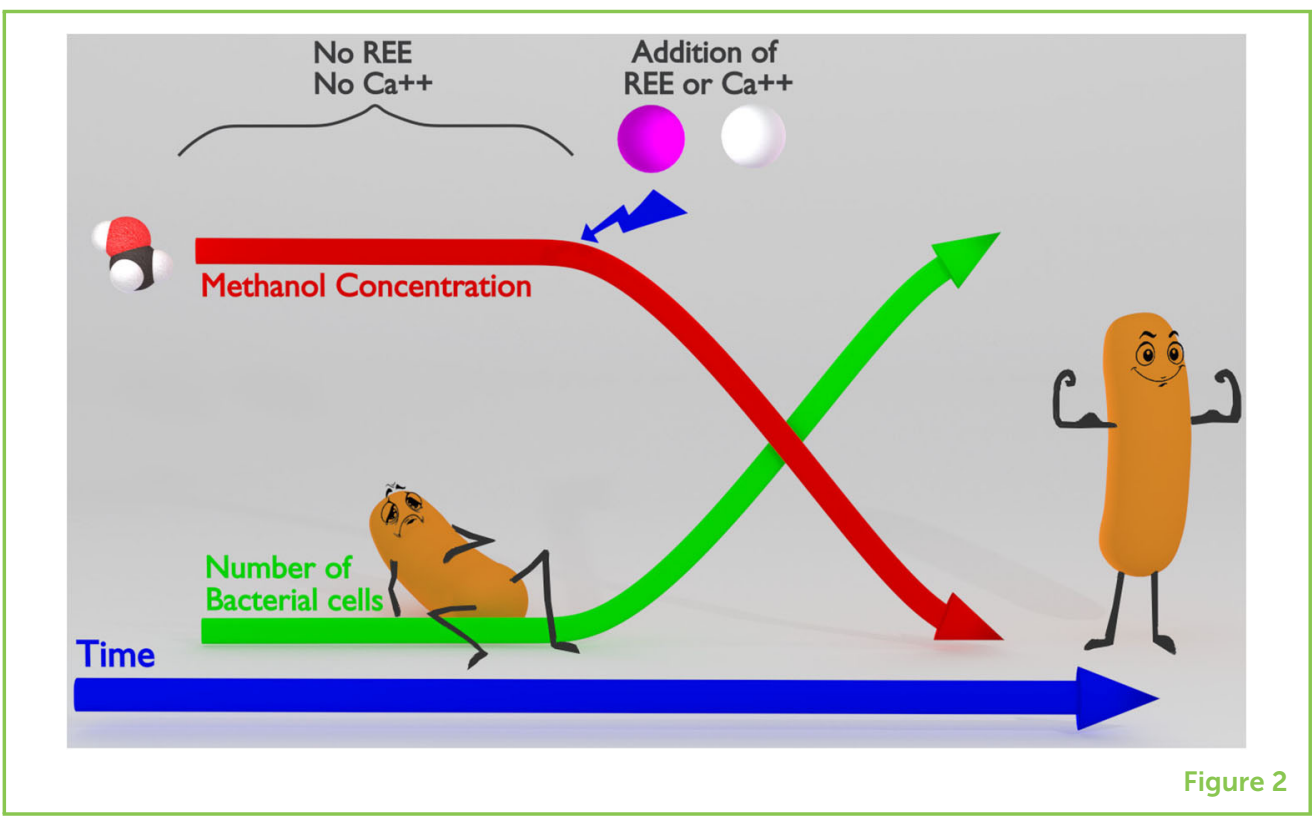

\section{HOW DO REES HELP BACTERIA "EAT" ALCOHOL?}

It has been known for a long time that several types of bacteria, called methylotrophic bacteria, can use the alcohols ethanol or methanol as food. This is unusual, because these alcohols are very toxic to other organisms, including humans! Many years of research on methylotrophic bacteria showed that some of them need the element calcium to consume methanol. Further discoveries showed that at least some bacteria could consume methanol and ethanol using REEs instead of calcium [4, 5]. Additionally, some methylotrophic bacteria have been found to eat another substance, called methane. Those bacteria first convert methane into methanol and then they consume it. Methane is one of the gases that contributes to the greenhouse effect, so bacteria that consume it are essential for maintaining the appropriate temperature conditions on Earth, which means they are critical for life on our planet.

The methanol-eating bacteria live in many different places, including the roots and leaves of various kinds of plants [6, 7]. This is probably because those plants produce methanol and release it to the environment. Surprisingly, some plants not only release methanol, but also release a lot of other molecules that are valuable for the bacteria. So, plants are like supermarkets for microorganisms! (Figure 3).

\section{WHAT DISCOVERIES DO WE FORESEE IN THE FUTURE?}

REE are metallic elements that can be found in diverse environments. They are useful for different industries and for daily life. Their importance in living organisms was unknown until recently when it was realized that many bacteria need REE for consuming alcohol, 
Figure 3

Bacteria live on plants so they can use substances that are found on leaf surfaces. Some plants produce methanol, which methylotrophic bacteria living on their leaves can eat in the presence of REEs or calcium. Plant leaves can also produce other substances that are useful for the bacterial growth, such as sugars, and amino acids - like a supermarket for bacteria!

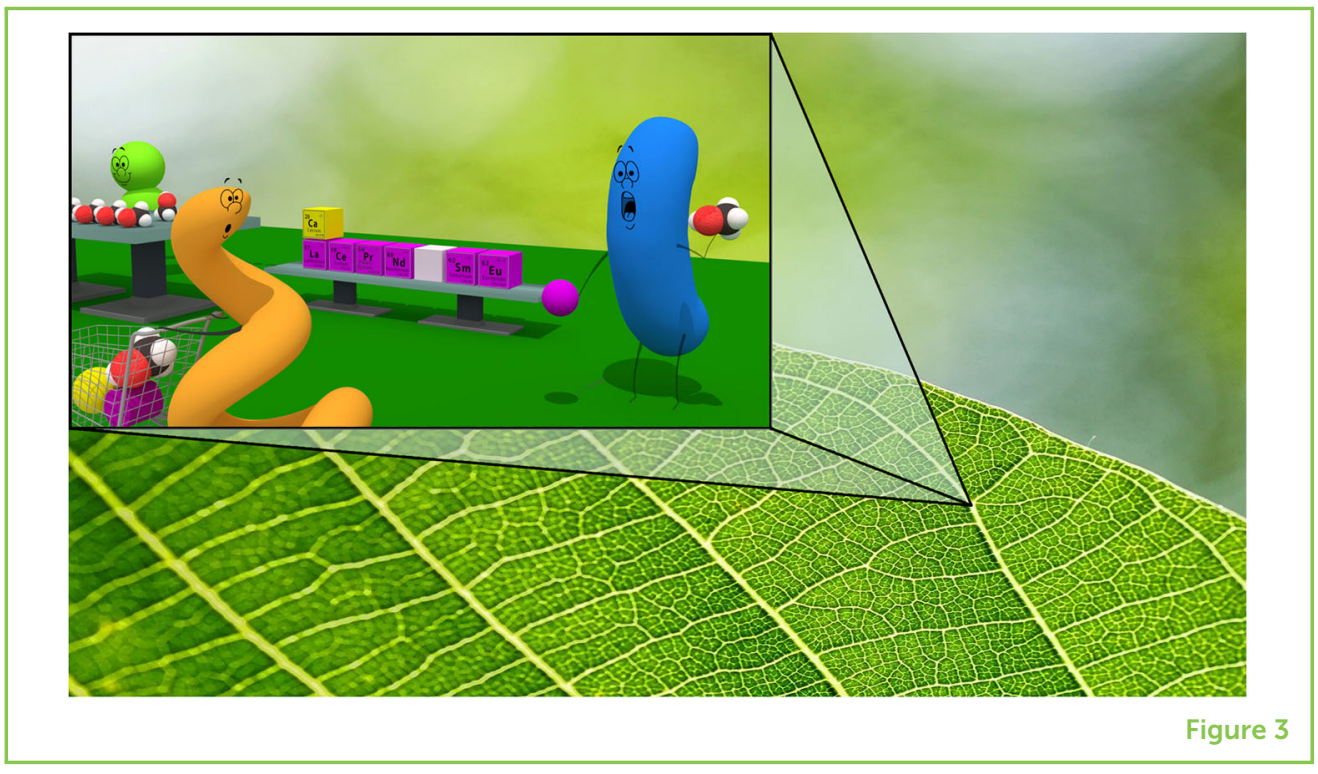

methanol and methane. Currently, several research groups around the world are studying diverse topics related to REEs, so it is expected that there will be many new discoveries. As time goes on, we will gain more knowledge about how bacteria use REEs, and we might even find other organisms that use REEs. This knowledge could help us to mine REEs in an environmental friendly way or to decontaminate REE polluted places.

\section{ACKNOWLEDGMENTS}

We thank Chiara Fuentes for their help with preparing Figure 1.

\section{REFERENCES}

1. Fitriyanto, N. A., Fushimi, M., Matsunaga, M., Pertiwiningrum, A., Iwama, T., and Kawai, K. 2011. Molecular structure and gene analysis of $\mathrm{Ce}^{3+}$-induced methanol dehydrogenase of Bradyrhizobium sp. MAFF211645. J. Biosci. Bioeng. 111:613-7. doi: 10.1016/j.jbiosc.2011.01.015

2. Hibi, Y., Asai, K., Arafuka, H., Hamajima, M., Iwama, T., and Kawai, K. 2011. Molecular structure of $\mathrm{La}^{3+}$-induced methanol dehydrogenase-like protein in Methylobacterium radiotolerans. J. Biosci. Bioeng. 111:547-9. doi: 10.1016/ j.jbiosc. 2010.12.017

3. De Simone, G., Polticelli, F., Aime, S., and Ascenzi, P. 2018. Lanthanides-based catalysis in eukaryotes. IUBMB Life 70:1067-75. doi: 10.1002/iub.1933

4. Huang, J., Yu, Z., Groom, J., Cheng, J. F., Tarver, A., Yoshikuni, Y., et al. 2019. Rare earth element alcohol dehydrogenases widely occur among globally distributed, numerically abundant and environmentally important microbes. ISME J. 13: 2005-17. doi: 10.1038/s41396-019-0414-z 
5. Good, N. M., Vu, H. N., Suriano, C. J., Subuyuj, G. A., Skovran, E., and Martinez-Gomez, N. C. 2016. Pyrroloquinoline quinone ethanol dehydrogenase in Methylobacterium extorquens AM1 extends lanthanide-dependent metabolism to multicarbon substrates. J. Bacteriol. 198:3109-18. doi: 10.1128/JB.00478-16

6. Bustillos-Cristales, M. R., Corona-Gutierrez, I., Castañeda-Lucio, M., Águila-Zempoaltécatl, C., Seynos-García, E., Hernández-Lucas, I., et al. 2017. Culturable facultative methylotrophic bacteria from the cactus Neobuxbaumia macrocephala possess the locus XOXF and consume methanol in the presence of $\mathrm{Ce}^{3+}$ and $\mathrm{Ca}^{2+}$. Microbes Environ. 32:244-51. doi: 10.1264/jsme2.ME 17070

7. Fedorov, D. N., Doronina, N. V., and Trotsenko, Y. A. 2011. Phytosymbiosis of aerobic methylobacteria: new facts and views. Microbiology 80:443-54. doi: $10.1134 /$ S0026261711040047

SUBMITTED: 14 January 2020; ACCEPTED: 07 December 2020; PUBLISHED ONLINE: 13 January 2021.

EDITED BY: Martha Helena Ramírez-Bahena, University of Salamanca, Spain

CITATION: Bustillos-Cristales R, Pedraza-Pérez Y and Fuentes-Ramírez LE (2021) How Rare Are Rare-Earth Elements in Living Things? Front. Young Minds 8:526870. doi: $10.3389 /$ frym.2020.526870

CONFLICT OF INTEREST: The authors declare that the research was conducted in the absence of any commercial or financial relationships that could be construed as a potential conflict of interest.

COPYRIGHT @ 2021 Bustillos-Cristales, Pedraza-Pérez and Fuentes-Ramírez. This is an open-access article distributed under the terms of the Creative Commons Attribution License (CC BY). The use, distribution or reproduction in other forums is permitted, provided the original author(s) and the copyright owner(s) are credited and that the original publication in this journal is cited, in accordance with accepted academic practice. No use, distribution or reproduction is permitted which does not comply with these terms.

\section{YOUNG REVIEWER}

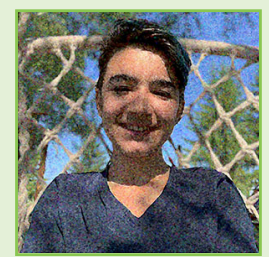

\section{KONSTANTIN, AGE: 14}

Hi I am Konstantin, your nearby Young Mind! I am from Rousse, Bulgaria and since I was little I had questions like: what is the point in recycling etc. Now, as an adolescent, I really got into ecology and decided to help bring awareness of some of the problems in our world has like the air pollution, species extinction, and deforestation. If I, an ordinary student, can make a difference you can too-so what are you waiting for my young reader! 

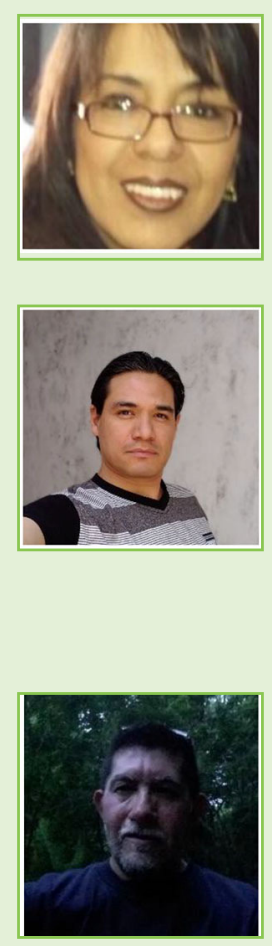

\section{LUIS ERNESTO FUENTES-RAMÍREZ}

My interest is the ecology of plant-associated bacteria. We have studied the bacteria living in different kind of plants, including sugar cane, pineapple, and cacti. I enjoy my work, walking outdoors, having a good time with friends, reading novels, jogging, traveling, watching sports, and cooking. *luis.fuentes@correo.buap.mx 